DEBATE

\section{Gripe aviária: epidemiologia dos casos de infecção humana pelo virus H5N1}

Avian influenza: the epidemiology of cases of human infection by $\mathrm{H} 5 \mathrm{~N} 1$ virus
Promed-Port@promedmail.org publicou notícia extraída do Boletim Epidemiológico da OMS com atualização de dados epidemiológicos de 205 casos de infecção humana por virus H5N1, ocorridos até 30 de abril de 2006. Reproduzimos essa notícia, no contexto do Debate que promovemos a respeito dessa ameaça à população global.

Fonte: Alerta y Respuesta ante Epidemias y Pandemias (EPR) [30.06.2006] http://www.who.int/csr/don/2006_06_30/ es/index.html

Gripe aviar: epidemiologia de los casos de infeccion humana por virus H5N1 notificados a la OMS

El boletin Weekly Epidemiological Record-Releve epidemiologique hebdomadaire, publicado en linea por la OMS, presenta los resultados del primer analisis de los datos epidemiologicos de los 205 casos de infeccion por virus H5N1 confirmados mediante pruebas de laboratorio que se han notificado oficialmente a la OMS entre diciembre de 2003 y el 30 de abril de 2006.

Los datos utilizados en el analisis fueron recogidos con fines de vigilancia. Su calidad, fiabilidad y formato no son uniformes en los diferentes paises, pero a pesar de ello se considero que permitirian extraer varias conclusiones.

El número de nuevos paises que han notificado casos aumento de 4 a 9 despues de octubre de 2005, tras la extension geografica de los brotes aviares.
La mitad de los casos ocurrieron en menores de 20 anos, y el $90 \%$ en menores de 40 anos.

La tasa de letalidad global fue del $56 \%$. La letalidad fue alta en todos los grupos de edad, pero sobre todo en el de 10 a 39 anos.

Esta distribucion de la letalidad por grupos de edad es distinta de la observada en la gripe estacional, en la que la mortalidad es mas elevada en los ancianos.

La tasa de letalidad global mas elevada (73\%) se registro en 2004 , seguida de lo que va de 2006 (63\%) y de 2005 (43\%).

Las tasas de mortalidad y los intervalos entre el inicio de los sintomas y la hospitalizacion y la muerte indican que las caracteristicas de la enfermedad no han cambiado de forma sustancial durante estos tres anos.

Ha habido casos a lo largo de todo el ano. No obstante, la mayor incidencia de casos humanos se ha registrado en cada uno de los tres anos durante el periodo correspondiente al invierno y la primavera en el hemisferio norte. Si continua esta tendencia, habra que prever un aumento del numero de casos a finales de 2006 o principios de 2007.

Con el fin de mejorar la monitorizacion de la situacion, la evaluacion del riesgo y el tratamiento de los pacientes infectados por virus $\mathrm{H} 5 \mathrm{~N} 1$, es necesario que los paises recojan los datos epidemiologicos de un modo mas uniformizado y los compartan opor 